\title{
Phenoxazinone Synthase from Streptomyces antibioticus: Purification of the Large and Small Enzyme Forms
}

\author{
HENRY A. CHOY AND GEORGE H. JONES \\ Department of Cellular and Molecular Biology, Division of Biological Sciences, \\ The University of Michigan, Ann Arbor, Michigan 48109 \\ Received February 4, 1981
}

\begin{abstract}
Phenoxazinone synthase has been purified approximately 80 -fold from 48 -h-old cells of Streptomyces antibioticus. The purification procedure involves streptomycin sulfate and ammonium sulfate precipitations, affinity and Bio-Gel chromatography, and glycerol gradient centrifugation. Two forms of the enzyme are purified by these techniques, a large form (L) with a molecular weight of around 900,000 and a small form (S) with an $M_{\mathrm{r}}$ of about 200,000 . Electrophoresis of the large and small forms on sodium dodecyl sulfate-polyacrylamide gels reveals the presence of a single polypeptide chain with a molecular weight of around 100,000. Both $L$ and $S$ appear to be distinct molecular forms of the enzyme since rechromatography on Bio-Gel or recentrifugation on glycerol gradients results in retention of the mobility of the form in question. These procedures do not convert $L$ to $S$ or $S$ to $L$. The puriflcation procedure described has been used for the preparation of phenoxazinone synthase from 12-, 18-, and 48-h cultures of $S$. antibioticus. These experiments have shown that the relative amounts of $L$ and $S$ which can be isolated depend on the age of the cells used as starting material. As the cultures age, the relative amount of $\mathrm{L}$ which is present increases. This result also suggests that $\mathrm{L}$ and $\mathrm{S}$ are distinct molecular entities. Antibody to a combined $L$ plus $S$ preparation and to $L$ has been raised in rabbits. Anti- $\mathrm{L}$ antibody reacts with both $\mathrm{L}$ and $\mathrm{S}$ and is capable of completely inhibiting phenoxazinone synthase activity in crude extracts of $S$. antibioticus cells. Thus, the $100,000 M_{\mathrm{r}}$ subunits of $\mathrm{L}$ and $\mathrm{S}$ must have some antigenic determinants in common, although they may not be identical in structure. Oxygen consumption during the formation of cinnabarinic acid from 3-hydroxyanthranilic acid was measured with the Clark oxygen electrode. These experiments showed that both $\mathrm{L}$ and $\mathrm{S}$ catalyze a reaction involving the consumption of $1.5 \mathrm{~mol}$ of oxygen per mole of phenoxazinone formed.
\end{abstract}

Streptomyces antibioticus is a grampositive actinomycete which produces the antibiotic, actinomycin (1). Much study has been devoted to the changes in macromolecular synthesis which precede and accompany actinomycin production in this organism. For example, it has been found that there is a significant decline in the levels of protein and RNA synthesis in growing cells as they prepare to make actinomycin (2-4). Some of the changes in the translational apparatus appear to be related to the function of the cells in actinomycin biosynthesis (5). In addition, it has been observed that actinomycin-producing $S$. antibioticus cells are capable of synthesizing significant quantities of RNA while they are producing actinomycin (4, 6). Several mechanisms by which they protect themselves against the inhibitory action of the antibiotic have been discovered $(3,7)$.

In contrast to the amount of information which is available regarding the regulation of macromolecular synthesis in $S$. antibioticus, very little is known about the mechanism of actinomycin biosynthesis in this organism. Indeed, only two enzymes have been implicated in actinomycin biosynthesis to date. One of these is presumably involved in the activation of valine for incorporation into the pentapeptide chains of the antibiotic (8). This enzyme has not been well characterized. The sec- 
ond enzyme, originally named phenoxazinone synthetase by Katz and Weissbach (9), is involved in the synthesis of the actinomycin chromophore, actinocin. This enzyme has more recently and appropriately been named phenoxazinone synthase (10). Phenoxazinone synthase (PHS) ${ }^{1}$ catalyzes the condensation of two molecules of 4-methyl, 3-hydroxyanthranilic acid, and derivatives thereof, to yield actinocin and its derivatives. The enzyme was partially purified by Katz and Weissbach a number of years ago, and these workers reported several of its properties (10). However, it was not clear from their data that the enzyme preparation they obtained was homogeneous, nor did their purification scheme take into account the possible existence of multiple forms of the enzyme. Indeed, Golub and Nishimura detected the presence of several forms of the enzyme by gel electrophoresis (11). In view of these results, and because of the need for highly purified enzyme for use in the regulatory studies which are ongoing in this laboratory, it seemed necessary to devise a procedure for the complete purification of $S$. antibioticus phenoxazinone synthetase. The results of this purification are presented in this report.

\section{MATERIALS AND METHODS}

\section{Materials}

S. antibioticus were grown as described previously (3). Mycelia were harvested at various times after innoculation of galactose-glutamic acid medium (usually at $48 \mathrm{~h}$ ) and generally used immediately for the enzyme purification. 3-Hydroxyanthranilic acid (3HAA), phenylmethylsulfonyl fluoride (PMSF), Sepharose $4 B$, and streptomycin sulfate were all obtained from Sigma. Enzyme grade ammonium sulfate was from Schwartz/Mann. Cyanogen bromide and 3,3'-iminobispropylamine were from Aldrich.

\section{Enzyme Assay}

The phenoxazinone synthase assay was performed essentially as described by Katz and Weissbach (9). Three-milliliter reaction mixtures contained sodium

\footnotetext{
${ }^{1}$ Abbreviations used: PHS, phenoxazinone synthase; 3HAA, 3-hydroxyanthranilic acid; PMSF, phenylmethylsulfonyl fluoride; CBA, cinnabarinic acid; SDS, sodium dodecyl sulfate.
}

acetate, pH 5.0, $100 \mu \mathrm{M} ; 3 \mathrm{HAA}, 0.67 \mathrm{mM}$; and enzyme. Reaction mixtures were incubated at $25^{\circ} \mathrm{C}$ and the change in absorbance at $452 \mathrm{~nm}$ was measured at 5min intervals in a Gilford Model 2400 spectrophotometer over the course of 30-45 min. Enzyme activity was calculated from the linear portion of the absorbance vs time curves. One unit represents the amount of enzyme which catalyzes the formation of $1 \mathrm{nmol}$ of the phenoxazinone (cinnabarinic acid) in one minute of incubation under the conditions just described. The molar extinction coefficient for cinnabarinic acid is 18,000 (9).

\section{Purification of Phenoxazinone Synthase}

All steps were carried out at $0-4^{\circ} \mathrm{C}$ unless otherwise indicated.

Step 1. Forty-eight-hour mycelia from 2-3 liters of galactose-glutamic acid medium were collected by suction filtration and washed with $500 \mathrm{ml}$ of $50 \mathrm{~mm}$ Tris- $\mathrm{HCl}$, $\mathrm{pH} 7.6$, containing $1 \mathrm{M} \mathrm{KCl}$ and $1 \mathrm{~mm}$ PMSF (Buffer 1), followed by a wash with the same buffer without $\mathrm{KCl}$ (Buffer 2). In a typical experiment, 20 $\mathrm{g}$ (wet wt) of mycelia were ground with $30 \mathrm{~g}$ of alumina for $10 \mathrm{~min}$ in a chilled mortar and pestle. The grindate was then extracted with $50 \mathrm{ml}$ of Buffer 2 and the extract was centrifuged for $10 \mathrm{~min}$ at $17,000 \mathrm{~g}$. The supernatant from this centrifugation was set aside and the pellet was ground a second time for 5 $\mathrm{min}$ with $10 \mathrm{~g}$ of alumina. The grindate was extracted again and centrifuged as above and the supernatants were combined and denoted "crude extract."

Step 2. The crude extract was then brought to $1.25 \%$ streptomycin sulfate by adding the appropriate volume of a $5 \%$ solution which had been neutralized with $\mathrm{NH}_{4} \mathrm{HCO}_{3}$. The streptomycin sulfate was added dropwise, with stirring in the cold, over the course of about $5 \mathrm{~min}$. The suspension was then stirred for an additional $30 \mathrm{~min}$ and the precipitated nucleic acids were pelleted by centrifugation for 20 $\min$ at $20,000 \mathrm{~g}$.

Step 3. The supernatant from the streptomycin sulfate step was treated with solid ammonium sulfate $(176 \mathrm{mg} / \mathrm{ml}$ supernatant) added slowly with stirring. The suspension was stirred for $30 \mathrm{~min}$ and the resulting precipitate was collected by centrifugation as in step 2. The precipitate was discarded and the supernatant was again treated with solid ammonium sulfate $(127 \mathrm{mg} / \mathrm{ml})$ as just described. After centrifugation, the supernatant was discarded, and the pellet was dissolved in $20 \mathrm{ml}$ of a buffer consisting of $87 \mathrm{mM} \mathrm{NaH} \mathrm{PO}_{4}, 13 \mathrm{mM} \mathrm{Na} \mathrm{HPO}_{4}, 10 \%$ glycerol, 1 mM PMSF, pH 6.0 (Buffer 3).

Step 4. The enzyme was purified further by affinity chromatography. 3HAA was coupled to Sepharose to form an affinity support essentially as described by Marcus (12). Usually, $40 \mathrm{ml}$ of settled Sepharose $4 \mathrm{~B}$ in $40 \mathrm{ml}$ of distilled water was treated with $12 \mathrm{~g}$ 
of cyanogen bromide with vigorous stirring. The $\mathrm{pH}$ of the mixture was maintained at 10-11 by the addition of $5 \mathrm{~N} \mathrm{NaOH}$ and the temperature at $20^{\circ} \mathrm{C}$ by adding crushed ice as necessary. After base uptake ceased, additional crushed ice was added and the activated Sepharose was collected by suction filtration and washed with a liter of $0.2 \mathrm{M}$ sodium carbonate, pH 9. A linker arm was then attached by treating $40 \mathrm{ml}$ of the activated Sepharose with $40 \mathrm{ml}$ of $2 \mathrm{M}$ $3,3^{\prime}$-iminobispropylamine (titrated to $\mathrm{pH} 10$ with $\mathrm{HCl}$ ). The suspension was stirred for $21 \mathrm{~h}$ at $4^{\circ} \mathrm{C}$ when the resin was collected by suction filtration and washed with 1 liter of distilled water. 3HAA was coupled to the linker-Sepharose via its carboxyl group as follows. 3HAA, $4 \mathrm{mmol}$, was dissolved in 50 ml of dimethylformamide. The solution was brought to $120 \mathrm{ml}$ with water and $40 \mathrm{ml}$ of the linker-Sepharose was added. The suspension was stirred at room temperature for $1 \mathrm{~h}$ during which time the $\mathrm{pH}$ was maintained at 4.8 . The suspension was then transferred to the cold and stirred for an additional $17 \mathrm{~h}$. The affinity support was collected by suction filtration as above and washed over the course of 2

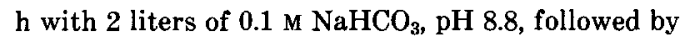
$200 \mathrm{ml}$ of water. As a result of this procedure $27 \mu \mathrm{mol}$ of $3 \mathrm{HAA}$ was attached per milliliter of packed sepharose. The support was generally stored in $1 \mathrm{M}$ $\mathrm{NaCl}$ containing a small amount of sodium azide.

For affinity chromatography, column bed volumes equivalent to 1.6 times the wet weight of starting mycelia were used. Chromatography was performed in $2 \times 25-\mathrm{cm}$ glass columns. The affinity support was washed and equilibrated with Buffer 3 . The enzyme solution from step 3 was applied and the column was then washed with Buffer 3 containing $0.2 \mathrm{M} \mathrm{NaCl}$ until the $A_{280}$ of the effluent was below 0.1. The enzyme was then eluted by washing the column with Buffer 3 containing $0.5 \mathrm{M} \mathrm{NaCl}$. Fraction volumes were usually one-fifth the bed volume of the affinity column and flow rate was $1.2 \mathrm{ml} / \mathrm{min}$. Appropriate fractions were assayed for enzyme activity as described above. A typical affinity column profile is shown in Fig. 1. Fractions 17-20 from this column were pooled and the enzyme was precipitated by the addition of $500 \mathrm{mg} / \mathrm{ml}$ of solid ammonium sulfate. After $30 \mathrm{~min}$ of stirring in the cold, the precipitated protein was collected by centrifugation for $20 \mathrm{~min}$ at $20,000 \mathrm{~g}$.

Step 5. The resulting precipitate was dissolved in a minimal volume of Buffer 3 containing $0.5 \mathrm{M} \mathrm{NaCl}$ and applied to a $1.6 \times 95-\mathrm{cm}$ column of Bio-Gel A5m, equilibrated and eluted with the same buffer. A typical column profile is shown in Fig. 2. Fractions 4572 from this column were pooled and precipitated with ammonium sulfate by dialysis without stirring as described previously (13). The precipitate was collected by centrifugation as in step 4 and dissolved in

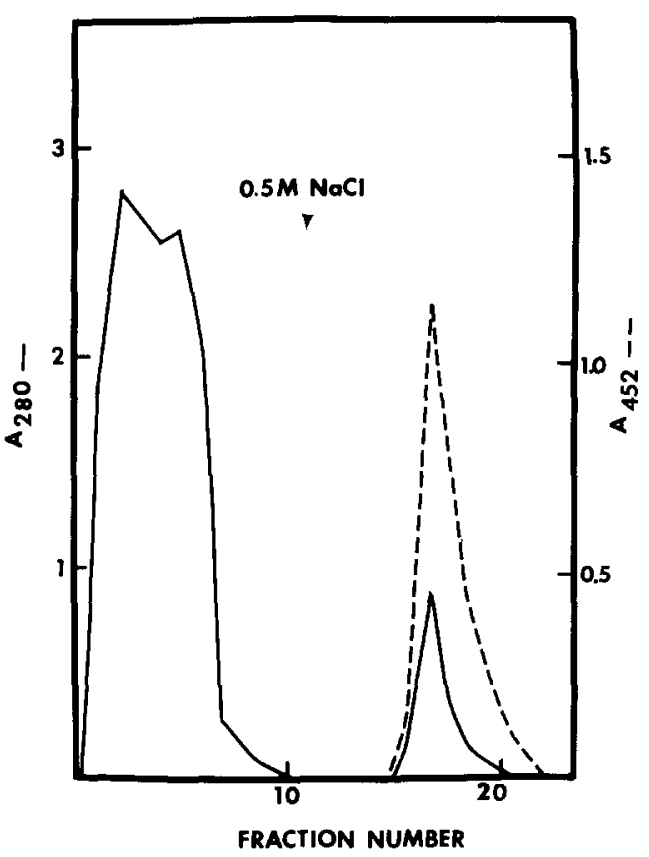

FIG. 1. Affinity chromatography of phenoxazinone synthase. Step 3 enzyme was applied to a $2 \times 11-\mathrm{cm}$ column of 3-hydroxyanthraniloyl-Sepharose. The column was washed first with Buffer 3 containing 0.2 M $\mathrm{NaCl}$ followed by Buffer $3 / 0.5 \mathrm{M} \mathrm{NaCl}$. Flow rate was $72 \mathrm{ml} / \mathrm{h}$ and $6-\mathrm{ml}$ fractions were collected. Fractions were pooled as indicted in the text.

Buffer 3 containing $0.5 \mathrm{M} \mathrm{NaCl}$ to give a final volume of 1.2-1.5 ml. In some experiments it was observed that more efficient separation of the large and small enzyme forms could be achieved by pooling fractions 45-58 and 59-70, concentrating and fractionating each pool separately on glycerol gradients as described below.

Step 6. Step 5 enzyme was applied in 200 - to 250 $\mu l$ aliquots to $5 \mathrm{ml} \mathrm{20-40 \%} \mathrm{glycerol} \mathrm{gradients} \mathrm{pre-}$ pared in Buffer 3/0.5 M NaCl. Gradients were centrifuged for 8-10 h at 50,000 rpm in the Beckman SW 50.1 rotor. Following centrifugation, tubes were punctured and 8- to 9-drop fractions were collected from each tube. A typical gradient profile, depicting the separation of the enzyme activity into large $(\mathrm{L})$ and small (S) forms is shown in Fig. 3. L- and Scontaining fractions were pooled and stored at $-70^{\circ} \mathrm{C}$ or concentrated by ammonium sulfate precipitation as described in step 5 .

\section{Preparation of Antibody to PHS}

In a typical experiment, $2 \mathrm{mg}$ of PHS form $\mathrm{L} \mathrm{ob}$ tained from glycerol gradients or from the Bio-Gel column were thoroughly emulsified with Freund's 


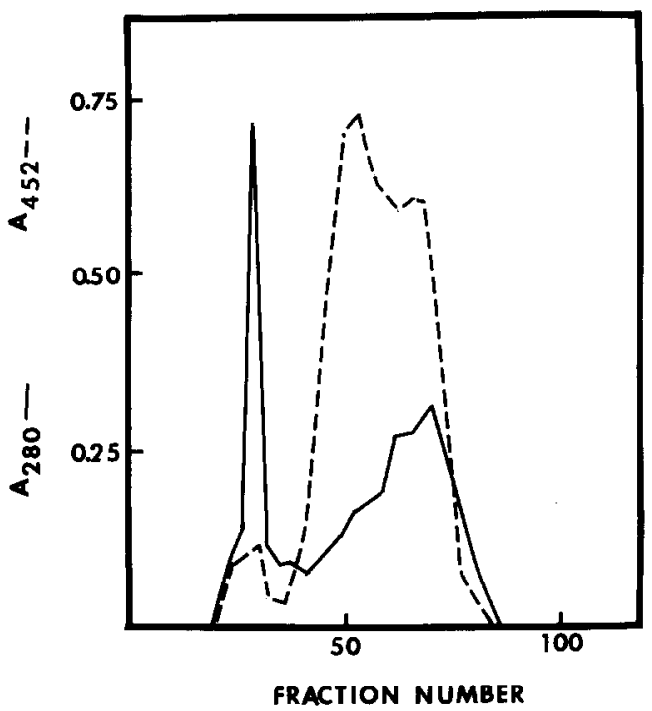

FIG. 2. Bio-Gel A5m chromatography of phenoxazinone synthase. Concentrated step 4 enzyme was applied to a $1.6 \times 95-\mathrm{cm}$ column of Bio-Gel A5m. The column was eluted with $0.5 \mathrm{M} \mathrm{NaCl}$ in buffer 3 at a flow rate of $27 \mathrm{ml} / \mathrm{h}$ and $2-\mathrm{ml}$ fractions were collected. Enzyme-containing fractions were pooled as indicated in the text.

complete adjuvant. The emulsion was injected either subcutaneously or intramuscularly into a New Zealand white rabbit. After 2 weeks the animal was given a booster injection with $1 \mathrm{mg}$ of enzyme in incomplete Freund's administered subcutaneously. Two weeks later the animal was bled from the ear. Serum was obtained by low-speed centrifugation of the blood and immunoglobulins were precipitated from the serum by adding solid ammonium sulfate to $50 \%$ saturation. The resulting precipitate was collected by centrifugation as described above, dissolved in a minimal volume of $50 \mathrm{mM}$ sodium phosphate buffer, $\mathrm{pH} 7$, containing $0.15 \mathrm{M} \mathrm{NaCl}$ and dialyzed against two changes of the same buffer. Normal serum was obtained in the same fashion prior to immunization. Sera were stored at $-70^{\circ} \mathrm{C}$.

\section{Measurement of Oxygen Consumption}

Oxygen consumption in the phenoxazinone synthase-catalyzed conversion of 3HAA to cinnabarinic acid (CBA) was measured using the Clark oxygen electrode. The clectrode cuvette contained $2.75 \mathrm{ml}$ of enzyme assay mixture prepared as described above. The reaction was initiated by the addition of enzyme and a stable rate of oxygen consumption was established as judged by the linearity of the recorder tracing. At this point (usually 1-2 min after enzyme addition) $0.25 \mathrm{ml}$ was removed from the reaction mixture and pipetted into $0.75 \mathrm{ml}$ of $0.5 \mathrm{M}$ EDTA, $\mathrm{pH}$ 7. The time of removal of this aliquot was noted and the reaction was allowed to proceed for 1-3 additional $\min$. At that time, a second $0.25-\mathrm{ml}$ aliquot was removed as above and the time again noted on the recorder chart. The absorbance of the two aliquots at $452 \mathrm{~nm}$ was determined and these values were used to calculate the amount of cinnabarinic acid formed during the time interval over which the measurement was made. The amount of oxygen consumption was determined from the electrode recorder tracing using a value of $250 \mu \mathrm{M}$ as the oxygen concentration of the buffer at saturation.

\section{Miscellaneous Methods}

Sodium dodecyl sulfate-polyacrylamide gel electrophoresis (SDS-PAGE) was performed essentially as described by Laemmli (14). Electrophoresis of enzymes on nondenaturing gels was performed essentially as described by Davis (15). Gels containing 59.5\% acrylamide monomer were run routinely. Molecular weights of $L$ and $S$ were determined by Ferguson analysis on nondenaturing gels. Gels of 5,6 , 7 , and $8 \%$ acrylamide monomer concentration were run. Five micrograms each of ovalbumin, bovine serum albumin, pyruvate kinase, and $\beta$-galactosidase were applied to each gel. Three to five micrograms of purified $\mathrm{L}$ and $\mathrm{S}$ were applied to separate gels. Protein standards were visualized by staining appropriate gels with Coomassie Brillian Blue while L and $S$ were visualized by incubating gels in the substrate mix described above. The mobility of bands on the gels was used to calculate the retardation coefficient $K_{\mathrm{R}}^{\prime}$, for Ferguson analysis according to Hedrick and Smith (16). Molecular weights of native phenoxazinone synthase enzymes were also estimated by glycerol gradient centrifugation using the equations of Martin and Ames (17).

Protein was determined by the method of Lowry et al. (18) or using the Bio-Rad protein assay reagent. The method of Layne (19) was frequently used to estimate protein concentrations in column or gradient fractions.

\section{RESULTS}

\section{Comments on the Purification}

As mentioned above, the enzyme under study was called phenoxazinone synthetase by Katz and Weissbach in their early publications (9) and, indeed, has been referred to by that name in reports from this laboratory (2-4). However, more recent studies with the enzyme have indicated that there is no ATP requirement for the condensation reaction (10). Thus, accord- 
ing to the Commission on Biochemical Nomenclature (20), the enzyme should formally be a synthase, not a synthetase. Thus, it will be referred to herein as phenoxazinone synthase.

A summary of a typical purification procedure is presented in Table I. The two forms of the enzyme are purified by about 80 -fold relative to the crude extract and are obtained in about $80 \%$ yield. It can be seen that the enzyme activity increases relative to the crude extract in purification steps 2-4. This observation suggests that inhibitors of the enzyme are removed during one or more of these steps and, indeed, a similar result was obtained in the purification of RNA polymerase from $S$. antibioticus (21). The yield of enzyme has varied in different experiments from 30 to $50 \mathrm{mg}(\mathrm{L}+\mathrm{S})$ per $100 \mathrm{~g}$ wet wt of mycelia. These enzyme yields represent 1$1.6 \%$ of the total protein present in crude extracts of $48-\mathrm{h}$ cells. The enzymes are quite stable and can be stored at $-70^{\circ} \mathrm{C}$ essentially indefinitely in pure form. Repeated freezing and thawing (up to five or six times) can be accomplished with only minimal losses in activity.

The affinity column step has proven very useful in the purification of the enzyme prior to Bio-Gel chromatography. The enzyme could be eluted from the column by
3HAA although the $\mathrm{NaCl}$ elution procedure was more efficient and less expensive. The fact that the enzyme bound very poorly to the linker-Sepharose (without 3HAA attached) suggests that the observed purification was indeed a result of the affinity of the enzyme for the substrate-resin complex.

A number of alternative procedures have also been explored for the purification of the enzymes, but these were generally less applicable than those described above. For example, it was observed that chromatography of step 2 enzyme on DEAE-cellulose gave low yields and highly variable results. Similarly, when ultracentrifugation was used as an alternative to streptomycin sulfate precipitation, it was observed that a significant amount of the enzyme activity pelleted along with the ribosomes. Preparative electrophoresis on nondenaturing gels was attempted for the separation of the PHS enzyme forms, and this procedure has, in fact, been used effectively for the purification of small quantities of radioactively labeled enzyme. However, the enzyme yields from this procedure were too low to permit its use as a large-scale purification technique. The procedure described under Materials and Methods can easily be scaled up or down and has been applied to quantities

TABLE I

PURification of Phenoxazinone Synthase from $S$. antibioticus ${ }^{a}$

\begin{tabular}{|c|c|c|c|c|c|c|c|}
\hline Step & & $\begin{array}{l}\text { Volume } \\
\text { (ml) }\end{array}$ & $\begin{array}{l}\text { Protein } \\
\text { (mg) }\end{array}$ & $\begin{array}{l}\text { Activity } \\
\text { (units) }^{b}\end{array}$ & $\begin{array}{l}\text { Specific } \\
\text { activity }^{c}\end{array}$ & $\begin{array}{c}N \text {-fold } \\
\text { purification }\end{array}$ & $\begin{array}{c}\text { Percentage } \\
\text { Yield }\end{array}$ \\
\hline 1. Crude extract & & 75 & 599 & 27,000 & 45.1 & - & 100 \\
\hline $\begin{array}{l}\text { 2. Streptomycin } \\
\text { sulfate }\end{array}$ & & 100 & 462 & 31,000 & 67.1 & 1.5 & 115 \\
\hline $\begin{array}{l}\text { 3. Ammonium } \\
\text { sulfate }\end{array}$ & & 25 & 329 & 45,830 & 139 & 3.1 & 170 \\
\hline $\begin{array}{l}\text { 4. Affinity } \\
\text { column }\end{array}$ & & 4.2 & 63.5 & 44,100 & 694 & 15.4 & 163 \\
\hline 5. Bio-Gel & & 1.2 & 16.4 & 38,640 & 2356 & 52.2 & 143 \\
\hline $\begin{array}{l}\text { 6. Glycerol } \\
\text { gradient }\end{array}$ & $\begin{array}{l}\mathrm{L} \\
\mathrm{S}\end{array}$ & $\begin{array}{l}1.0 \\
1.0\end{array}$ & $\begin{array}{l}4.1 \\
2.1\end{array}$ & $\begin{array}{r}15,700 \\
7,240\end{array}$ & $\begin{array}{l}3829 \\
3448\end{array}$ & $\begin{array}{l}84.9 \\
76.4\end{array}$ & $84.9^{d}$ \\
\hline
\end{tabular}

a Starting from $20 \mathrm{~g}$ of $48-\mathrm{h}_{\mathrm{h}}$ cells.

${ }^{b}$ Defined as under Materials and Methods.

${ }^{c}$ Units/mg protein.

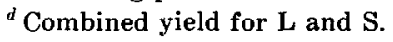


of $48-\mathrm{h}$ cells as small as $5 \mathrm{~g}$ and as large as $150 \mathrm{~g}$.

\section{Purity of the Enzymes}

As shown in Fig. 3, the separation of step 5 enzyme by glycerol gradient centrifugation results in two symmetrical peaks of enzyme activity and the figure also shows that the protein profile corresponds exactly to the profile of enzyme activity. It should be noted that protein concentrations in the gradient were estimated by the method of Layne (19). Thus, the specific activities of $L$ and $S$ are most accurately reflected by the data of Table I. The data of Fig. 3 do suggest that the glycerol gradient produced homogeneous $\mathrm{L}$ and $\mathrm{S}$ enzyme forms. This suggestion has been confirmed by SDS-PAGE as shown in Fig. 4. Electrophoresis of both $L$ and $S$ produces a single band on the gel and this band has the same apparent $M_{\mathrm{r}}$ for both enzyme forms (see further below).

In most cases, efficient separation of $\mathrm{L}$ and $S$ can be achieved by a single gradient centrifugation of step 5 enzyme. In some

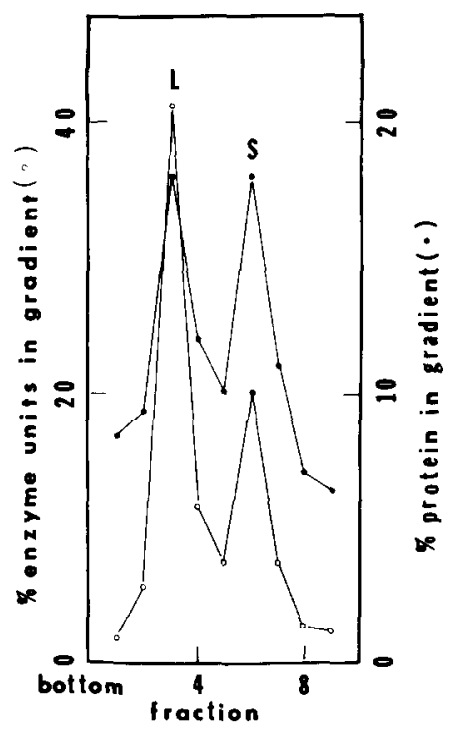

FIG. 3. Glycerol gradient centrifugation of step 5 enzyme. Two hundred-microliter aliquots of the concentrated step 5 enzyme were applied to each of six 20-40\% glycerol gradients. Gradients were centrifuged and analyzed as described in the text. Fractions 2-4 and 6-8 were pooled and concentrated.

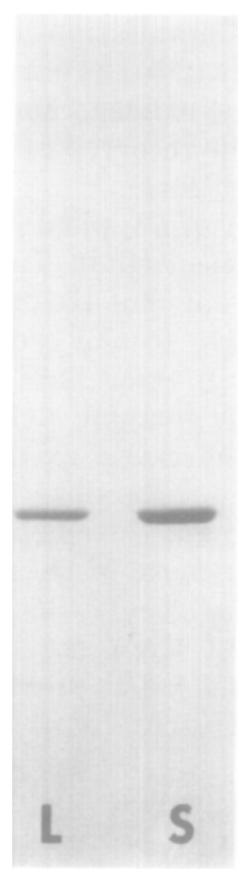

FIG. 4. Electrophoresis of phenoxazinone synthase on SDS-gels. The acrylamide concentration was $9.5 \%$ and gels were prepared as described by Laemmli (13). Ten micrograms of $\mathrm{L}$ and $15 \mu \mathrm{g}$ of $\mathrm{S}$ were applied to the gel slab. Following electrophoresis, gels were stained overnight with Coomassie Brilliant Blue and destained.

cases, however, it has been necessary to recentrifuge the $\mathrm{L}$ and $\mathrm{S}$ fractions from the first gradient a second time to accomplish a complete separation of the two forms. As is shown in Fig. 2, some separation of $L$ and $S$ is provided by the gel filtration chromatography on Bio-Gel A5m. Indeed, the leading edge of the enzyme activity peak (fractions $44-51$ of Fig. 2) contains essentially pure form $L$ and this material has sometimes been used in the preparation of anti-L antibody. Form $\mathrm{S}$ from Bio-Gel is generally contaminated not only with $L$ but also with other extract proteins as well, and the glycerol gradient centrifugation is required to obtain homogenous S. A preparation of $\mathrm{L}+\mathrm{S}$ which is free of other contaminants can be obtained by pooling the fractions from the Bio-Gel column as specified under Materials and Methods and rechromatographing the pooled enzyme on the same column 
eluted with Buffer 3 without $\mathrm{NaCl}$. This low-salt chromatography effectively removes most of the contaminants from the pooled $\mathrm{L}$ and $\mathrm{S}$ preparation.

\section{Size and Subunit Molecular Weights of $L$ and $S$}

As shown in Fig. 4, SDS-PAGE of L and S on $9.5 \%$ gels produces a single polypeptide band. Comparison of the mobility of this band with appropriate electrophoretic standards indicates an $M_{\mathrm{r}}$ of 97,000 (Fig. 5). Electrophoresis on gels with monomer compositions of $8.5-10 \%$ have yielded molecular weights of $97,000-103,000$, with an average value of $99,500 \pm 2500$. The molecular weights of the native $L$ and $S$ forms have been estimated by comparison of their sedimentation properties with those of appropriate standards of known $M_{\mathrm{r}}$ ( $\beta$-galactosidase, $M_{\mathrm{r}} 538,000 ;$ Escherichia coli RNA polymerase holoenzyme, $M_{\mathrm{r}}$ 493,000; S. antibioticus RNA polymerase, $M_{\mathrm{r}} 400,000$; pyruvate kinase, $M_{\mathrm{r}} 237,000$ ). These analyses yield native molecular weights of 919,000 for $L$ and 237,000 for $S$. The native molecular weights of $L$ and $S$ have also been determined by electrophoresis on $7.5 \%$ nondenaturing acrylamide gels (15) by Ferguson analysis, according

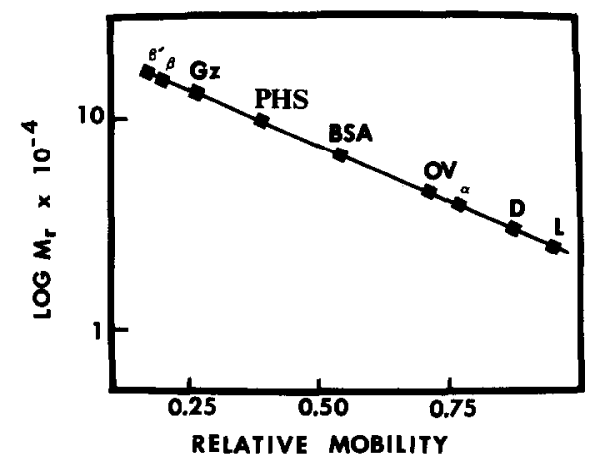

FIG. 5. Determination of the molecular weight of the $\mathrm{L}$ and $\mathrm{S}$ subunit. Gel electrophoresis was performed as described in the text and in the legend to Fig. 4. Molecular weight standards used in the determination were: the $\beta(155,000), \beta^{\prime}(165,000)$, and $\alpha(39,000)$ subunits of $E$. coli RNA polymerase, $\beta$ galactosidase $(\mathrm{Gz}, 135,000)$, bovine serum albumin (BSA, 68,000), ovalbumin (OV, 44,000), DNase I (D, $30,000)$, and immunoglobulin light chain $(\mathrm{L}, 25,000)$.

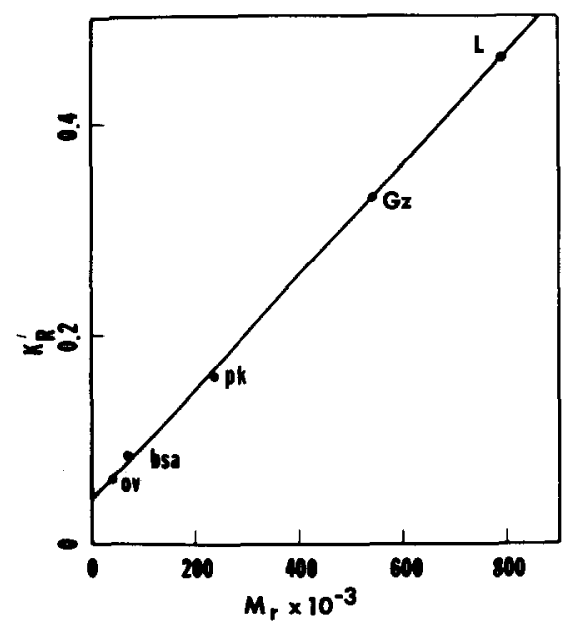

FIG. 6. Ferguson analysis of phenoxazinone synthase $\mathrm{L}$ and $\mathrm{S}$. Gels were run as described under Materials and Methods and analyzed according to Hedrick and Smith (16). It should be noted that $S$ migrated with pyruvate kinase at each acrylamide concentration. PK, Pyruvate kinase; other standards were as indicated in the legend to Fig. 5.

to Hedrick and Smith (16). In this procedure PHS and appropriate standards were electrophoresed on $5,6,7$, and $8 \%$ acrylamide gels as described under Materials and Methods. Results of such an experiment are shown in Fig. 6 in which the retardation coefficient, $K_{\mathrm{R}}^{\prime}$, is plotted against molecular weight. The molecular weight calculated for $\mathrm{L}$ from these experiments was 799,000 . S migrated identically to pyruvate kinase at each acrylamide concentration, indicating an $M_{\mathrm{r}}$ of 237,000 . These data suggest that $S$ is composed of two of the 99,500 $M_{\mathrm{r}}$ subunits and $\mathrm{L}$ is composed of eight or nine of these subunits. It has not yet been determined whether the $L$ and $S$ subunits are identical (see further below). Other molecular properties of the $\mathrm{L}$ - and $\mathrm{S}$ enzyme forms will be presented in a subsequent report.

Variations in the Relative Amounts of $L$ and $S$ with the Age of the $S$. antibioticus Culture

The availability of a quick and reasonably straightforward purification procedure for the $L$ and $S$ forms of phenoxa- 
zinone synthase has made it possible to examine $S$. antibioticus cells of varying ages to determine the relative amounts of these forms which are present in those cells. In these experiments, enzyme was purified from cells harvested 12,18 , and $48 \mathrm{~h}$ after innoculation into galactose-glutamic acid medium. The enzymes were purified through step 2 and were then applied directly to Bio-Gel A5m without the intervening affinity column step. The appropriate fractions from the Bio-Gel column were pooled, concentrated, and applied to glycerol gradients as described above. The relative amounts of $L$ and $S$ in these gradients were calculated by measuring the PHS activity in each gradient fraction and expressing this result as percentage of the total activity recovered from the gradient. Results of these experiments are shown in Fig. 7 and Table II. Figure 7 shows clearly that the relative amount of $L$ increases with the age of the cells and Table II provides quantitative data on the magnitude of this increase. These data show that the ratio of $L$ to $S$ increases from a value of 0.2 at $12 \mathrm{~h}$ to 2.2 at $48 \mathrm{~h}$. We have not yet examined the ratio in cultures older than $48 \mathrm{~h}$ or younger

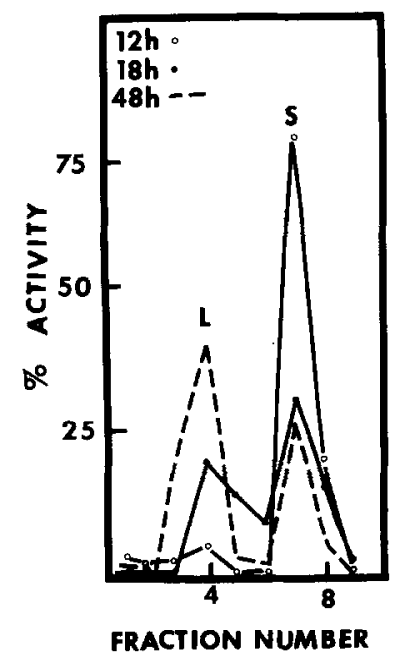

FIG. 7. Glycerol gradient centrifugation of step 5 enzyme from $S$. antibioticus cells of varying ages. Centrifugation procedures were as described in the text. Results are expressed as indicated in the text and in the legend to Table II.

\section{TABLE II}

RELATIVE AMOUNTS OF L AND S IN 12-, 18-, AND 48-h S. antibioticus CELLS ${ }^{a}$

\begin{tabular}{ccc}
$\begin{array}{c}\text { Cell age } \\
(\mathrm{hr})\end{array}$ & $\begin{array}{c}\text { Percentage } \\
\mathrm{L}\end{array}$ & $\begin{array}{c}\text { Percentage } \\
\mathrm{S}\end{array}$ \\
\hline 12 & 16.4 & 83.6 \\
18 & 45 & 55 \\
48 & 69 & 31 \\
\hline
\end{tabular}

a Relative amounts of $\mathrm{L}$ and $\mathrm{S}$ were measured as described in the text. Results are expressed as percentage of total activity recovered from glycerol gradients as $\mathbf{L}$ or $\mathrm{S}$.

than $12 \mathrm{~h}$. As has been shown in several previous reports, the total amount of PHS also increases with the age of the cells (2, $3,7,22$ ).

\section{Preparation of Antibody to PHS}

Antibody to PHS L was prepared as described under Materials and Methods. This antiserum produced a single precipitin band on Ouchterlony double-diffusion plates when reacted with the immunizing antigen (data not shown). In addition, it has been shown that antibody to $\mathrm{L}$ will react with $S$, again producing a single precipitin line. These experiments have been extended using preparations of radioactive $L$ and $S$, purified from cells grown in the presence of radioactive amino acid (usually $\left[{ }^{35} \mathrm{~S}\right] \mathrm{methionine).} \mathrm{In} \mathrm{these} \mathrm{exper-}$ iments, the ability of anti-L to precipitate radioactive $L$ and $S$ has been measured in test tube precipitation reactions. In a typical experiment, in which equal amounts of $L$ and $S$ protein were treated with the same amount of antiserum, anti-L precipitated $44 \%$ of the radioactive $\mathrm{L}$ and $53 \%$ of the radioactive $\mathrm{S}$. These results indicate that, while the 99,500-dalton subunit of $\mathrm{L}$ may not be identical to that of $S$, they must at least possess antigenic determinants in common. Other data supporting the conclusion that $L$ and $S$ are similar in structure were provided by the experiment of Fig. 8. In this experiment, antibody to L was used to precipitate PHS from crude extracts of $48-h S$. antibioticus cells. It can 


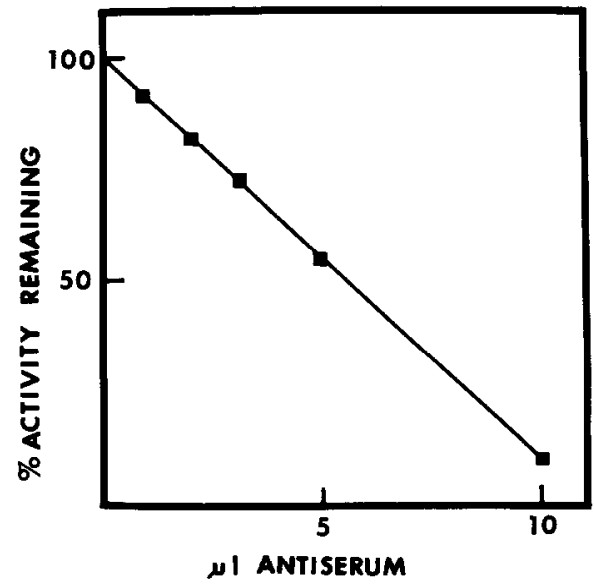

FIG. 8. Inhibition of PHS activity by anti-L antihody. Reaction mixtures contained $460 \mu \mathrm{g}$ protein of a crude $S$. antibioticus extract and varying amounts of anti-L antibody as indicated in the figure. Mixtures were brought to a total volume of $200 \mu \mathrm{l}$ by the addition of phosphate-buffered saline, and incubated for $18 \mathrm{~h}$ in the cold. Immunoprecipitates were pelleted by centrifugation and the resulting supernatants were tested for enzyme activity as described in the text. Control incubation mixtures contained normal rabbit or no serum at all.

be seen that the anti- $\mathrm{L}$ antibody is capable of completely inhibiting the PHS activity in the 48-h cell extract.

\section{Oxygen Consumption in the Phenoxazinone Synthase Reaction}

Katz and Weissbach reported in their original study of PHS, that the condensation reaction proceeded with the consumption of $1.5 \mathrm{~mol}$ of $\mathrm{O}_{2}$ per mole of phenoxazinone formed (9). However, since it was not clear from this report that their PHS preparation was homogenous, it seemed possible that the oxygen requirement they observed might have resulted from the presence of some other enzyme as a contaminant in their preparation. Further, it was of interest to determine whether oxygen consumption was observed with both PHS forms L and S which have been purified in this laboratory. To these ends, oxygen uptake during the condensation reaction was measured with the Clark oxygen electrode. The amount of CBA formed was also determined so that moles $\mathrm{O}_{2}$ per mole phenoxazinone could be calculated. Results of these experiments are presented in Table III. With enzyme $L$, data from three separate experiments gave an average ratio of $1.47 \mathrm{~mol}$ of oxygen consumed per mole of cinnabarinic acid formed, while with $\mathrm{S}$, the average was 1.51 $\mathrm{mol} / \mathrm{mol}$. These data are completely consistent, then, with the $\mathrm{O}_{2}$ consumption results and with the reaction scheme suggested by the experiments of Katz and Weissbach (9).

\section{DISCUSSION}

The data presented above mark the first report of the preparation of homogeneous phenoxazinone synthase. The procedure described under Materials and Methods is straightforward, reasonably simple, highly reproducible, and quick. Milligram quantities of pure $\mathrm{L}$ and $\mathrm{S}$ can be obtained in as little as 2 days. Further, as has already been stated, the purification procedure is easy to scale up or down to meet specific preparative needs. Previously published purification procedures $(9,11,23)$ took several days and generally required far larger quantities of starting material to yield enzyme amounts comparable to those obtained by the procedure reported here. Indeed, Katz and Weissbach obtained only about $3 \mathrm{mg}$ of enzyme $/ 100 \mathrm{~g}$ of mycelia (9) and Golub and Nishimura obtained only about $4 \mathrm{mg}$ of enzyme $/ 100 \mathrm{~g}$ of mycelia (11). Yields as high as $30-50 \mathrm{mg} / 100$ $\mathrm{g}$ of mycelia can be obtained by the procedures described in the present report. Further, neither of the two other purification schemes cited above included a procedure for the preparative separation of the multiple enzyme forms. It should be noted that the assay procedure used in the experiments reported here was slightly different from that employed by Golub and Nishimura (11), and Katz and Weissbach (9), who performed the assay incubations at $37^{\circ} \mathrm{C}$. We have tested the activity of a combined $\mathrm{L}$ and $\mathrm{S}$ preparation at $37^{\circ} \mathrm{C}$ and, using the definition of an enzyme unit specified by Katz and Weissbach, we obtain a specific activity of 290 units/mg protein. Katz and Weissbach re- 
TABLE III

OXYGEN CONSUMPTION IN THE PHS REACTION ${ }^{a}$

\begin{tabular}{ccccc}
\hline Exp & $\begin{array}{c}\text { Enzyme } \\
\text { form }\end{array}$ & $\begin{array}{c}\text { CBA } \\
\text { formed } \\
(\mathrm{nmol})\end{array}$ & $\begin{array}{c}\mathrm{O}_{2} \\
\text { consumed } \\
\text { (nmol) }\end{array}$ & $\mathrm{O}_{2} / \mathrm{CBA}$ \\
\hline 1 & $\mathrm{~L}$ & 100 & 125 & 1.25 \\
2 & & 57.2 & 93.8 & 1.64 \\
3 & $\mathrm{~S}$ & 66.1 & 100 & 1.51 \\
4 & & 49.4 & 81.3 & 1.64 \\
5 & 50 & 68.8 & 1.38 \\
\hline
\end{tabular}

\footnotetext{
${ }^{a}$ Reaction mixtures contained $54 \mu \mathrm{g}$ (Exp 1) or $27 \mu \mathrm{g}$ (Exps 2 and 3) of $\mathrm{L}$ or $24 \mu \mathrm{g}$ of $\mathrm{S}$. The average value for $\mathrm{O}_{2} / \mathrm{CBA}$ is 1.47 for experiments $1-3$ and 1.51 for experiments 4 and 5 .
}

ported a value of 220 units/mg for their purified enzyme (9). Our data suggest that PHS represents $1-2 \%$ of the total protein present in 48-h $S$. antibioticus cells which is comparable to the values which can be calculated from the data of Katz and Weissbach and Golub and Nishimura $(9,11)$.

The preparation of the $L$ and $S$ forms of PHS raises the question whether these two forms are distinct molecular entities or whether they may be related to each other by some simple association-dissociation equilibrium. Several lines of evidence suggest that no simple equilibrium aggregation phenomenon is involved. First, the data of Fig. 7 show that the relative amount of $\mathrm{L}$ increases as $S$. antibioticus cultures age. Mycelia harvested after 12 $h$ of growth contain very little $L$, but a significant amount of $\mathrm{S}$. Thus, $\mathrm{S}$ cannot be converted to $\mathrm{L}$ simply as a result of the preparation of cell extracts for purification of the enzyme. Further, the behavior of $\mathrm{L}$ and $\mathrm{S}$ on rechromatography on BioGel and on recentrifugation on glycerol gradients has been examined. In both cases, $L$ and $S$ retain their original mobilities. No $L$ is converted to $S$ or $S$ to $L$ by rechromatography or recentrifugation. These data strongly suggest that $\mathrm{L}$ and $\mathrm{S}$ are stable forms of the enzyme. Further evidence in support of this conclusion will be presented in a subsequent report in which it is demonstrated that $L$ and $S$ have different molecular and catalytic properties.
As shown by the data of Fig. 4, both $\mathrm{L}$ and $\mathbf{S}$ are composed of a subunit with a molecular weight of around 100,000 . It is not known whether this subunit has an identical primary structure in both the $L$ and $S$ enzymes but the studies which have been performed with antibody to $L$ indicate that there must be considerable sharing of antigenic determinants between the two kinds of subunits if they are not, in fact, identical. Antibody to $L$ appears to react as well with radioactively labeled $S$ as with L. Further, antibody to $\mathrm{L}$ is capable of completely inhibiting the PHS activity of 48 -h crude extracts, indicating that both $\mathrm{L}$ and $\mathrm{S}$ are recognized by the antibody. We are currently examining the structure of the subunit of $L$ and $S$ by peptide mapping using radioactively labeled enzyme.

The question remains, what are the functions of the two enzyme forms in actinomycin biosynthesis. A fuller attempt to answer this question will be made in a subsequent report, but it is worth noting here that, by analogy with the enzyme systems involved in antibiotic biosynthesis in the bacilli, phenoxazinone synthase could be a multienzyme complex which is the catalyst for the synthesis of actinomycin. This possibility is currently under investigation in this laboratory.

\section{ACKNOWLEDGMENT}

This research was supported in part by a grant from the Horace H. Rackham School of Graduate Studies, The University of Michigan. 


\section{REFERENCES}

1. Waksman, S. A. (1968) Actinomycin-Nature, Formation and Activities, Wiley-Interscience, New York.

2. Jones, G. H., AND Weissbach, H. (1970) Arch. Biochem. Biophys. 137, 558-573.

3. JONES, G. H. (1976) Biochemistry 15, 3331-3341.

4. JoNES, G. H. (1975) J. Bacteriol. 124, 364-372.

5. JONES, G. H. (1977) J. Bacteriol. 129, 81-86.

6. JoNeS, G. H. (1975) Biochem. Biophys. Res. Commun. 63, 469-475.

7. Marshali, R., Redfield, B., Katz, E., AND WeissbaCh, H. (1968) Arch. Biochem. Biophys. 123, 317-323.

8. Walker, J. E., OtANi, S., AND PERLMAN, D. (1972) FEBS Lett. 20, 162-166.

9. KATZ, E., AND WeissBaCH, H. (1963) J. Biol. Chem. 238, 666-675.

10. Katz, E., AND Weissbach, H. (1970) in Methods in Enzymology (Tabor, H., and Tabor, C. W., eds.), Vol. 17A, pp. 549-553, Academic Press, New York.

11. Golub, E. E., AND Nishimura, J. S. (1972) J. Bacteriol. 112, 1353-1357.

12. MarCus, S. L. (1974) in Methods in Enzymology
(Jakoby, W. B., and Wilchek, M., eds.), Vol. 34, pp. 377-385, Academic Press, New York.

13. SChrier, M. H., ERni, B., AND Staehlin, T. (1977), J. Mol. Biol. 116, 727-753.

14. LAEMMLI, U. K. (1970) Nature (London) 227, 680685.

15. Davis, B. J. (1964) Ann. N. Y. Acad. Sci. 121, 404427.

16. Hedrick, J. L., And Smith, A. J. (1968) Arch. Biochem. Biophys. 126, 155-164.

17. MARTIN, K. G., AND AMES, B. N. (1961) J. Biol. Chem. 236, 1372-1379.

18. Lowry, O. H., Rosebrough, N. J., FARR, A. L., ANd Randall, R. J. (1951) J. Biol. Chem. 193, 265-275.

19. LAYNE, E. (1957) in Methods in Enzymology (Colowick, S. P., and Kaplan, N. O., eds.), Vol. 3, pp. 447-454, Academic Press, New York.

20. Commission on Biochemical Nomenclature. (1973) Enzyme Nomenclature, pp. 15-16, Elsevier, Amsterdam.

21. Jones, G. H. (1979) Arch. Biochem. Biophys. 198, 195-204.

22. Gallo, M., AND KatZ, E. (1972) J. Bacteriol. 109, 659-667.

23. Salzman, L. A., Weissbach, H., and Katz, E. (1969) Arch. Biochem. Biophys. 130, 536-546. 